\title{
School Teacher's Perceptions about Equity Challenges and Features in Secondary School Education
}

\section{Tahira Roohi ${ }^{1}$, Pervez Aslam Shami ${ }^{2}$}

${ }^{1} \mathrm{PhD}$ Scholar, Sarhad University of Science and Information Technology, Peshawar Pakistan.

${ }^{2}$ Professor, Department of Education, Sarhad University of Science and Information Technology, Peshawar Pakistan

\section{A B S T R A C T}

This study was conducted to investigate the vision and surveillance of secondary school teachers regarding features and challenges that hinder equity in secondary school education. The study aims to explore effects of two dimensions of equity i.e. fair and inclusive at secondary school education in Khyber Pakhtunkhwa. The descriptive survey method was utilized in this study. The researcher - made instruments consisted of open-ended questions were administered to the 100 secondary school teachers of four districts i.e. Hangu, Karak, Peshawar and Haripur of Khyber Pakhtunkhwa. The study illustrate that the teachers preview the stipulation of fair and inclusive education system and design, resources, and curriculum are very crucial aspects that hinder the equity in secondary school education. To some extent, the features regarding secondary school teacher's lesson planning, and students' reward and punishment are encumbering the equity in education. Most of the teachers consider that Khyber Pakhtunkhwa Elementary and Secondary Education Department (KPESE) have a chief role in the provision of an equitable secondary school education. On the basis of finding the conclusion was drawn and possible recommendations were suggested.

KEYWORDS: Teachers, Equity, Fair and inclusive, Secondary school education.

\section{INTRODUCTION}

The purpose of education is to develop an individual and society. Islamic teachings direct both males and females to acquire education. The Constitution of Pakistan, as well as UN Charter education and individual, receive just treatment without any bias. After 18 amendments the article 25A- Right to Education of the Constitution says that: "The State shall provide free and compulsory education to all children of the age of five to sixteen years in such manner as may be determined by law". Pakistan being alive to the needs has formulated National Education Policy, 2009 having four major thrust areas- Access, Equity, Quality, and Governess. Equity in education means providing opportunities to all students- both male and females to develop themselves to

Address of Correspondence

Tahira Roohi

tahiraroohi@hotmail.com

\section{Article info}

Received Feb 03, 2017

Accepted April 03, 2018

Published April 30, 2018 
their fullest potentials and elimination of such factors that restrict educational achievements. It involves special consideration to reverse the historical and social disadvantages that prevent learners from accessing and benefiting on equal grounds (World Education Forum, 2015).

Equity in education means that personal or social circumstances such as gender, ethnic origin or family background, are not obstacles to achieving educational potential (fairness) and that all individuals reach at the least basic minimum level of skills (inclusion). In these education systems, the vast majority of students have the opportunity to attain high-level skills, regardless of their own personal and social-economic circumstances (Field et al, 2007). Equity embodies the idea of fairness and inclusion with reference to some dissimilarity in education progresses rather than the concept of sameness when dealing with a diverse student population (OECD, 2012). In the light of this scenario, the KPESE has the mandate to provide fair and inclusive education to elementary and secondary school students. For this era, they focus to provide the equitable system and design, practices, and resources to all secondary schools.

An equitable education system can redress the effect of broader social and economic inequalities. In the context of learning, it allows individuals to take full advantage of education and training irrespective of their background (Faubert, 2012; Field, Kuczera and Pont, 2007; Woessmann and Schutz, 2006). The benefits from education are enormous. Fair and inclusive education is enviable in KPESE schools because, Equity incorporates students' access to the school, material and human resources and educational processes and practices that are vital to achieving desired educational goalmouths in secondary school education. It spells out that the students having different localities want to enjoy due opportunities in a choice of schools teaching learning set up to avoid imbalance and bias. (Cohen, 1989; Levin, 2009).

The OECD report (2007) detailed that "Equitable education system is fair and inclusive and support their students to reach their learning potential without either formally or informally pre-setting barriers or lowering expectations". In this illumination, the secondary school teachers of Khyber Pakhtunkhwa perceptions are noteworthy that hamper the equity. Richardson \& Sandoval, (2007) highlighted that 
without an intergenerational understanding of discrimination beyond the schools, little change or constructive remedies can occur. We must continue to seek equity so that boys and girls are treated fairly in schools and are equally prepared for a wide range of careers.

- Fairness infers that personal and social circumstances such as gender, socioeconomic status or ethnic origin should not be a hindrance to educational success.

- Inclusion implies a minimum standard of education for all. (OECD, 2007, p.29).

\subsection{Factors Affecting Equity in Secondary School Education}

- The structure of the education system and the opportunities it provides

- Early childhood education through different pathways in secondary education

- Teaching practices and delivering in classroom

- Human and financial resources

- Curricular differences and organizational policies and practices etc. (Field et al, 2007 p. 51).

These factors may be categorized into three main headings i.e.

1. Design

2. Practices

3. Resources

The Khyber Pakhtunkhwa schools need to be equitable in the secondary school system i.e. secondary school design, secondary school practice, and secondary school resources.

\subsection{Secondary School Education Design}

Secondary school design is a fundamental element for attaining an equitable secondary school education in KP. Find a way through an education system is a challenge for everyone. The design of the education system matters a lot specifically in developing areas like KP, Pakistan. To select an effective school, track and subject is not an easy task. It bears equity in education. If the selection is appropriate the whole secondary education completion gives fruitful results. Causa and Chapuis (2009) captured the accurate picture of the school system and design as, "some system level policies, such as 
grade repetition or early tracking, tend to amplify socioeconomic disparities and are conducive to disengagement and dropout, whereas other policies seem to mitigate them".

The secondary school's students are categorized into different pathways according to their academic performance. All educational systems use academic selection at some stage. Mortimore et al. (2005) shared their Hungry secondary education system experience as, "popular secondary schools may organize an entrance exam". In Norway, "for lower secondary schools, there is virtually no selection on the grounds of academic record". So, it is concluded that KPESE academic selection hinders the learning of those who are not selected for the following reasons:

- Poor quality education

- Lack of benefits from the peer-group effect

- Stigma

- Unreliable sorting (Brunello et al. 2004).

Early student selection is a common practice in developing and developed countries. According to OECD Report (2012, p.58) "Students selection can take different forms, and is often based on academic performance". The median age of first formal selection is 15 years in OECD countries, in Finland and Spain students are not separated into different tracks until the end of lower secondary education. However, in a few countries such as Austria and Germany, selection takes place very early, when students are just 10 years old (OECD, 2010b). In the light of such experiences, the KPESE should have some specific criteria for tracking and streaming at grade 9. "Universal access to primary education may still produce weak coverage at the secondary school education level. Access to secondary school continues to be very limited in the developing world. Only $20 \%$ of the appropriate age group (both and girls) are enrolled in secondary school in sub-Saharan Africa: Latin America has the highest secondary school enrollment, with about $54 \%$ of the relevant age group compared, to industrialized countries whose average is 91\%" (Stromquist 2010 p.34). Mortimore et al., (2005) highlighted the rank of guidance and counseling in this stage as "the quality and adequacy of counseling vary enormously, and support for potential dropout from school is often inadequate. The 
guidance and counseling services need to engage more fully with the professions (OECD, 2012).

\subsection{School and Out-of School Practices}

Educating a person basically means fostering his or her individual development as a unique, self-determined, knowledgeable person who gradually gains an inability to participate in society. School-based instruction is the core process of formal and systematic education in KPESE schools (PISA, 2015). The teachers have the vision to inculcate the proper secondary school practices in KP schools. For this purpose, the knowledge base of educational effectiveness research allows for the identification of core factors:

$\checkmark$ Teachers' qualifications,

$\checkmark$ Teaching practices and classroom climate,

$\checkmark \quad$ Learning time and learning opportunities provided both within and out of school (Scheerens and Bosker, 1995; Creemers and Kyriakides, 2008).

Grade repetition is costly and ineffective in raising educational outcomes. Alternative strategies to reduce this practice include:

- Preventing repetition by addressing learning gaps during the school years;

- Automatic promotion or limiting repetition to subject or modules failed with targeted support;

- Raising awareness to change cultural support to repetition.

To support these strategies,

- complementary policies need to reinforce schools and teachers' capacities to respond appropriately to students' learning needs,

- To provide early, regular and timely support (OECD, 2012 p. 89)

To avoid the cost and ineffectiveness of repeating years of disadvantaged school and students' of KPESE, it is important to start change practices in our secondary schools which are at the heart of the education system. The way they deliver education can contribute to improving fairness and inclusion e.g. Luxembourg has introduced a reform to reduce the use of year repetition (Luxembourg, 2005), and in France, the Council for 
School Evaluation has recommended a reduction in its use (Haut del'E'valuation de 'E'cole, 2004).

The educational researchers suggested that a positive climate have a powerful and significant impact on student achievement and well-being in disadvantaged schools (Garcia Palomer and Paredes, 2010; Riley and Cloeman, 2011). We know that however, not all KPESE students are high academic achievers, and we need to be mindful to also communicate that we value non-academic attributes that our students exhibit, such as helpfulness, friendliness, creativity, problem-solving, and conflict resolution" (Jennings, 2015 p.148). It is the fact that nothing is more important than educating young people for creativity, and an education system that is focused on learning how to learn and on lifetime learning”. (Stiglitz, and Greenwald, 2015 p. 25). To fulfill the approach of fair and inclusive secondary school practices the KPESE should remember that essential skills for learning is teacher and teaching variables that include teachers' personality, ability and skills that enable him to present the subject matter (Gowda 2015, p. 227) because the term communication, to refer to all its processes: listening, reading, speaking, and writing (including use electronic and print media). (Taylor et al 2009).

Most education systems have different methods of providing special help to those with learning difficulties, although they are not always well evaluated specifically in KPESE schools. But both summative and formative approaches are valuable and both are considered integral in the learning process. Summative assessment summarizes a student's achievement at a particular moment in time (OECD, 2012). To achieve the fair and inclusive goals of secondary school practices it is a desire to involve the parents and community in school success. Because, "Today parents, educators, and policymakers recognize the need for a broad educational agenda that includes the development of social and emotional competencies. We want young people to learn to succeed academically, but we also want them to learn to manage relationships in skilled and respectful ways; practice positive, safe and healthy behaviors; make ethical and responsible contributions to their peer group, family, school, and community; and demonstrate basic competencies, work habits, and values as a foundation for meaningful life and engaged citizenship (Elias et al, 1997., Jackson, 2000., Learning First Alliance, 2001., Osher, Dwyer, \& 
Jackson, 2002., Jennings, 2015). Hence improvement in learning experiences for very young children is most effective if there is a commensurate level of involvement by parents and careers. (Smith, 1980; Edwards and Redfem, 1998; Nutbrown and Hannon, 1997; Allen and Duncan Smith, 2008; Allen, 2011; Rodger, 2012).

\subsection{Secondary School Resources}

Secondary school resources are an integral of fair and inclusive secondary school education. The research evidence highlighted the proper allocation and provision of direct and indirect resources. It is a general perception that while general increases in school funding do not necessarily improve student's outcomes (Woessman, 2008; Faubert, 2012). It prerequisites debate in case of KPESE school resources. This study illustrates that resources have a great impact on equity. As discussed earlier there are two main dimensions of equity- fairness and inclusion-imply two approaches:

- Directing more resources to students according to indicators of disadvantage or social need, e.g. family poverty addressing fairness; and

- Giving additional resources to students displaying learning weaknesses, addressing inclusion (Field et al, 2007).

For the attainment of equitable education system especially in Khyber Pakhtunkhwa, Elementary and Secondary Education (KPESE) needs to alter the low performing disadvantaged schools. Conceptual research suggests that a social justice orientation towards educational leadership practice and research promises to lead to a greater understanding of "how institutionalized theories, norms, and practices in schools and society lead to social, economic, and educational inequities (Dontley and Tillman, 2006, p.17). The role of the teacher is to foster children's' intellectual development through a systematic focus on symbolic representation. The environment is the key to children being able to explore and express themselves through all of their 'expressive' communicative and cognitive languages' (Edwards and Redfem 1998:7). Skilled practitioners should spend most of their time interacting rather than writing things down (DfE 2011 a: 30).

\subsection{Theoretical Framework}


This study utilized open-ended questions. The theoretical framework below was developed for the purpose of this study.

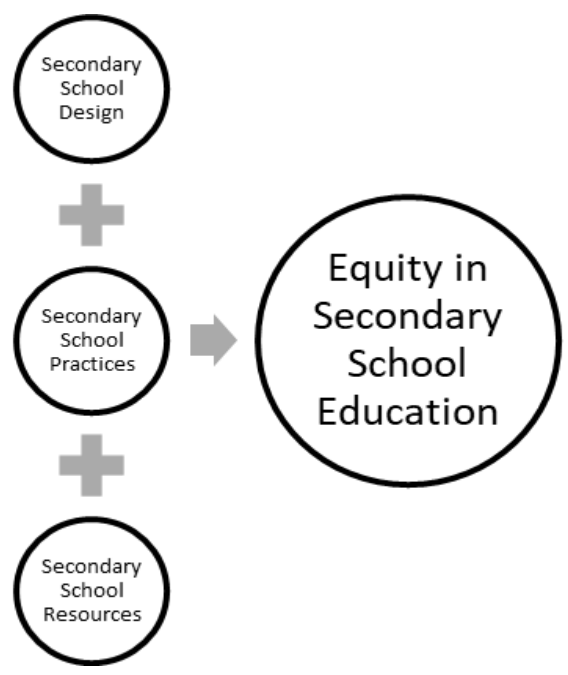

\subsection{Problem Statement}

This study was conducted to investigate the vision and sight of secondary school teachers regarding equitable secondary school education. Specifically, it aimed to answer the following;

i. What are very hinder equity features?

ii. What are their effects on secondary school education?

\subsection{The significance of the Study:}

Any investigation is done for some reasons. The result of this study significantly benefits the following group of people:

1. The head teachers as the primary group that will benefit from the results of this study as this will help to determine the equity challenges in secondary school education.

2. The educational managers will gain insights and will be able to develop educational strategies to lighten the obstructions that teachers encounter in their classroom teaching.

3. Through this study, the educational authorities will be more responsive to what help they can extend to the make the secondary school teachers feel that equitable education is a fruitful endeavor. 
4. The result of this study will enlighten the mind of other researchers and enrich their understanding of teachers' behavior and could be of great help to them when they conduct research on related issues.

\section{METHODOLOGY}

\subsection{Sample and Treatment of Collected Data}

This study was a descriptive survey that utilized a researcher - made an instrument as the main tool for gathering the data. The tool consisted of open-ended questions which were administered to the 100 teachers who were teaching the secondary school students of four sample districts i.e. Hangu, Karak, Peshawar, and Haripur. After the collection of the responded questionnaire, the gathered data were tailed. The measurement on what is the very difficult item of all the equity features that the teachers encountered was determined through qualitative description.

For analyzing the qualitative mode of open-ended responses of secondary school teachers, the researcher set the degree of measurements for purpose of interpretation as follows:

\begin{tabular}{|l|l|l|}
\hline $\begin{array}{l}\text { Frequency of } \\
\text { Secondary school teachers } \\
\text { Who give the item }(\%)\end{array}$ & Qualitative Description & Verbal Interpretation \\
\hline $\begin{array}{l}\text { When the number of } \\
\text { secondary school heads } \\
\text { are }\end{array}$ & $\begin{array}{l}\text { Few } \\
1 \text { to } 20\end{array}$ & $\begin{array}{l}\text { The difficulty of the item } \\
\text { is at }\end{array}$ \\
21 to 50 & $\begin{array}{l}\text { Some } \\
51 \text { to } 80\end{array}$ & $\begin{array}{l}\text { Lajority } \\
\text { Most }\end{array}$ \\
81 to 100 & $\begin{array}{l}\text { Less great extent } \\
\text { Great Extent } \\
\text { Very great extent }\end{array}$ \\
\hline
\end{tabular}

\section{RESULTS AND DISCUSSION}

The data pertained to the features and challenges that hinder the equity by secondary school teachers' perceptions of Khyber Pakhtunkhwa.

Challenges and Features Hinder the Equity in Secondary School Education. The table below portrays the 18 challenges and features considered by the secondary school 
teachers as challenges in fair and inclusive secondary school education. They are arranged based on how frequent they are pointed out by the secondary school educators.

\begin{tabular}{|c|c|c|c|c|}
\hline S.No & Items & Frequency & $\begin{array}{l}\text { Qualitative } \\
\text { Description }\end{array}$ & $\begin{array}{l}\text { Verbal } \\
\text { Interpretatio } \\
\mathbf{n}\end{array}$ \\
\hline 1. & Secondary school system & 100 & \multirow{5}{*}{ Most } & \multirow{5}{*}{$\begin{array}{l}\text { Very great } \\
\text { extent }\end{array}$} \\
\hline 2. & $\begin{array}{l}\text { Secondary school education } \\
\text { resources }\end{array}$ & 90 & & \\
\hline 3. & $\begin{array}{l}\text { Secondary school education } \\
\text { design }\end{array}$ & 85 & & \\
\hline 4. & Secondary school curriculum & 82 & & \\
\hline 5. & $\begin{array}{l}\text { School resources and role of } \\
\text { KP }\end{array}$ & 81 & & \\
\hline 6. & Classroom management & 78 & \multirow[t]{2}{*}{ Majority } & \multirow{2}{*}{ Great Extent } \\
\hline 7. & Teachers' attention & 50 & & \\
\hline 8. & Lesson planning & 50 & \multirow{3}{*}{ Some } & \multirow{3}{*}{$\begin{array}{l}\text { Less great } \\
\text { extent }\end{array}$} \\
\hline 9. & Use of $\mathrm{A} / \mathrm{V}$ Aids & 35 & & \\
\hline 10. & Reward and punishment & 21 & & \\
\hline 11. & Assessment & 18 & \multirow{8}{*}{ Few } & \multirow{8}{*}{ Least extent } \\
\hline 12. & Parents participation & 10 & & \\
\hline 13. & $\begin{array}{l}\text { Secondary school monitoring } \\
\text { system }\end{array}$ & 10 & & \\
\hline 14. & NEP and role of KP & 8 & & \\
\hline 15. & Lesson delivery & 7 & & \\
\hline 16. & Students scholarships & 5 & & \\
\hline 17. & $\begin{array}{l}\text { Treatment of a different group } \\
\text { of students }\end{array}$ & 2 & & \\
\hline 18. & $\begin{array}{l}\text { Secondary school educational } \\
\text { services }\end{array}$ & 1 & & \\
\hline
\end{tabular}

The data pertained to the equity in secondary school education. The table shows the 18 items considered by secondary school teachers in conducting a research study. They are enlisted based on how frequent they are pointed out by the SSTs.

The analysis of the study demonstrated that most of the secondary school teachers supposed that the first five items enumerated on table above are the items that contributed very great extent of secondary school resources, design, system, curriculum and role of education ministry of Khyber Pakhtunkhwa in provision of fair and inclusive secondary 
school education; however, item No.1 which refers to the secondary school system was felt to be the most important one in the provision of fair and inclusive education. One male teacher of district Peshawar depict regarding the KPESE education system;

[An].. if the KPESE give individual attention instead of the group than the educational system can be changed.

One female of the same district highlighted the importance of the secondary school system as;

"Fair and inclusive education is totally dependent upon the secondary school system if the system is proper than practice and resources will be accurate".

One male respondent from district Hangu discussed that how the social and economic background of poor student make hurdles in their achievement as;

[An] if KPESE wants to attain the desired goals of equity in secondary education then the authorities should focus to facilitate the poor background students to take benefits from their abilities.

One male practitioner from district Haripur gives suggestion regarding individual attention for the individual student as;

"......for providing individual attention to meet the individual need of every student, it is required to establish new schools and classrooms to adjust the students equally".

The same teacher further enhances the discussion regarding guidance and counseling as;

It is the need of the era to arrange sessions on social and psychological needs to provide guidance and counseling in selecting track and subjects. So, keeping in sight the importance of such presentation the administration should arrange the campus for students. School effectiveness is totally depended upon school system. In the same discussion, the provision of quality education at KPESE level, one female respondent of district Peshawar represent that,

We need some standards, time frame and practices in admission and promotion in class 9th. Without this put into practice, we cannot attain good results in Board of Intermediate and Secondary Education. Talking about secondary school design one district Haripur and one district Hangu female educators shared their personal views as; 
The students came here with different types of mentalities; they are unable to choose the subjects or tracks. It is much possible to provide them guidance or counseling to select the track. Item 2 and 3 which refer to the secondary school resources and design were also felt to be most important, one female and one male participant of the rural area of district Peshawar depicted the same views,

[An] Government of Khyber Pakhtunkhwa should provide resources according to the location wise population.

.... Secondary school teachers of all four sample districts were agreed that;

Provision of resources need keen attention; Lack of resources poorly affects the students' performance. Provision of proper furniture, proper school building and classrooms according to the strength of the students should make possible on an emergency basis. Answering the question regarding student failure and grade repetition one Karak practitioner enhance the discussion as;

It is a waste of economic resources and not good for a future generation. But it is also a fact that grade repetition also improves the students' academic performance. In highlighting the importance of the teacher training session's one female teacher of district Karak narrates that; we are living in the global village; to meet the advancement the subject specialist should have the regular chance of teacher training workshops without gender and location biases.

Another female gender of the same district illustrates the sensitive issue regarding teaching area as;

Promotion on performance should be encouraged instead of seniority. We have a couple of teachers of C.T. and PTC qualification, who are unable to teach the primary classes are teaching at the secondary level.

In drawing attention on resource allocation one male respondent of district Peshawar discussed the process of school budget preparation as;

[An] our school head repeats the previous budget every year so, future demand is not fulfilled. We face a lack of resources in our school. In the analysis of the research study instituted that majority of secondary school teachers assumed the next item 4 detailed on the table above is the item that added great extent of the secondary school curriculum; 
which was felt to be an important one in the provision of equitable education at secondary school level. One male participant from district Haripur emphasized that secondary school curriculum need to improve for the attainment of fair and inclusive education as;

[An] In KPESE system there is no share of individual attention to each and every student. The syllabus is not designed according to students' need. After completion of secondary school education, the students are not able to match the career development. Another female respondent of district Peshawar continue the discussion on the same item captured her views on item 4 i.e. present secondary school curriculum meeting the need of every individual student as;

..... individual differences are found among the students, but our course books need to design in such a way that students can find the solution of their such issues.

Added her opinion regarding the conceptual clarity of secondary school course content a female teacher of district Hangu depicted; Syllabus is not easy to understand. Majority of students come from government primary schools, due to weak learning abilities they are unable to catch the concepts of course material. So the results are substandard.

In discussing the cultural and social values in the curriculum, one male educator from district Peshawar and Karak have the same opinion; There is no moral lesson at the end of each and every lesson or topic. Most of the materials in the books' lesson have been taken from the internet. It is not compatible with our cultural values. The syllabus should be framed according to the need of students; the expertise should have focused on the following two questions,

- What type of language do they want to learn?

- For what purpose do they want to learn? etc.

So, there is a great need to design syllabus according to the wish of the future student. The curriculum should equalize so that students from private sector school's rash to government schools. The district Haripur male teacher enhanced the discussion on the same as; 
"Course material should represent the national, social, and cultural values of the society. The authorities should introduce short subjects in secondary schools to avoid the burden on students. The curriculum needs to review regularly".

It can be noted also in the analysis that two aspects to consider with great extent, i.e. secondary school classroom management and teachers' attention. To accomplish the fair and inclusive KPESE system it is the desire of the day to follow the Klieme et al (2009) suggested dimensions for teaching process, 1. Structure and classroom management 2. Teacher support and 3. Cognitive challenges. The four sample districts educators' emphases the classroom management and teachers' attention greatly. One male participant of district Peshawar underlines the timetable issue regarding classroom management;

[An] timetable should arrange according to the need of the subject content that teacher can finish their instructions in a given session.

One male respondent of district Hangu agreed that; "Research on effective classroom management points to the importance of teacher-student relationship" (Pianta, 2006) Another item 8, 9, and 10 was considered less great extent are; lesson planning, use of $\mathrm{A} / \mathrm{V}$ aids and reward and punishment. In answering the question regarding lesson planning one male teacher of district Peshawar depict that;

"We want to inspire the students' learning, but inspiration is not seen practically".

[An] The role of the teacher is always considered as a change agent. Every teacher should be loyal with students. The importance of projected and non-projected A/V aids are always in the discussion. One female SST demanded that;

School administration should provide proper $\mathrm{A} / \mathrm{V}$ aids for classroom learning. The need for multimedia and digital screen is going up. To meet such obstacles, the projected learning $\mathrm{A} / \mathrm{V}$ aids should arrange to improve the students learning. Moreover, the consequences divulged that out of eighteen items, eight of them were portrayed by the teachers as items which contributed the least extent in the provision of fair and inclusive secondary school education. This signifies that these items give only a little degree of complexity in the provision of equitable secondary school education.

\section{FINDINGS}


This study pertained to features and challenges that hinder equity in the perceptive of secondary school teachers in secondary school education. The teachers were grouped in four sample district i.e. Hangu, Karak, Peshawar, and Haripur secondary school education. Finding illustrate that the items which contributed a very great extent to the inequitable secondary school education are secondary school system \& design, resources, and curriculum. All secondary school teachers who served as the respondents of this study found it as crucial hinders of equity.

The secondary school teachers' lesson planning, students' reward, and punishment and use of $\mathrm{A} / \mathrm{V}$ aids in classroom learning were considered less great extent as equity challenges in secondary school education. The student's assessment, the parent's involvement in students learning and student's scholarships etc were judged as very least extent to acquire the equitable secondary school education.

\section{CONCLUSION}

In the light of this study, the researcher concluded that the secondary school system and design are the key elements in the provision of fair and inclusive secondary school education. Until and unless the secondary school system does not focus on the individual needs of the individual students the desired goal of equity cannot be achieved. The selection of school, proper tracking at grade 9 and enhancement of the basic minimum level of skills are the chief sources which make an equitable education system at the secondary school level. "The design of education systems can either increase or diminish initial inequities" (Field et al, 2007 p.67). To avoid such matters, the KPESE system and design need to repair of the secondary school education regarding the option to parents in school choice, selection of suitable track or stream at grade 9 and attaining at least basic minimum skills. The provision and allocation of school resources need to justify the equity targets. The educational expenditures either they are direct (school funding, need and merit base students' scholarships, a stipend for students' retention to complete the schooling for reducing the student's dropout and student's failure or school failure etc) or indirect (free text and exercise books etc) need to strengthen. 
To less great extent the secondary school practices as a concern to teacher's lesson planning, student's reward, and punishment, the teachers narrated that lesson planning according to students learning outcomes is burning issue of the current scenario. It is general authenticity that at its central, teaching is an emotional practice. The KP practitioner can influence their students constantly through the way they relate, teach, and model social and emotional concepts and manage the social and emotional dynamics of the classroom (Jennings, 2015 p.105). The teacher's vision and consideration were felt to some extent in the process of a student's assessment and parent's involvement in pupil's learning. The KPESE school assessment is a self-evaluation system that underpins a settings' ability to improve. In the best-organized settings of student's assessment, providers and staff reflect on the quality of their practice, assess what difference it makes to secondary school children's' welfare, learning and development, and plan accordingly. Weaker areas of KPESE students are recognized and change is adopted (Rodger, 2012. P.65). The overall goals and objectives of the KPESE curriculum are planned in advance through much deliberation and discussion by committed experts. Children are allowed freedom under the directions of the teacher in a choice of particular experiences by means of which the objectives of the curriculum are to be realized. Opportunities for collaborative and participatory learning are to be provided. Every child has the right and freedom to contribute to the process of curriculum transaction. But the teacher lends his professional guidance and direction as and when required (Gowda 2015, P.227).

\section{Future Recommendations}

The following recommendations are advanced:

1. The early tracking pretenses risk to equity so it needs to justify at the grade 9 level.

2. Academic selection and school choice poses risk to equity hence it necessitates being used with caution. The merit-based admission requires adopting.

3. The financial premiums to schools attracting disadvantaged students may also help (Field et al, 2007). The provision of maximum direct and indirect resources should make possible by KPESE department. 
4. Monitoring of the risk to equity features i.e. attendance, performance, and school activities should be improved to prevent student's failure and school failure.

5. Additional learning support should enhance to encourage students to stay in school.

6. To meet the need of individual student the regular appraisal of the secondary school curriculum makes possible.

7. The educational managers should require developing educational strategies to lighten equity challenges in secondary school education.

8. The educational authorities should need to more responsive to make equitable secondary school education.

\section{REFERENCES}

Abell Foundation (2001). Teacher certification reconsidered: Stumbling for quality. Baltimore, MD: Abell Foundation.

Allen, G. (2011) Early Intervention: The Next Step. An Independent Report to Her Majesty's

Government. London: The Centre for Social Justice. Available online at www.centreforsocialjustice.org.uk

Allen, G. MP and Duncan Smith, I.MP (2008) Early Intervention: Good Parents, Great Kids,

Better Citizens. The Centre for Social Justice. The Smith Institute: London.

Brunello, G., M. Gianni and K. Ariga (2004), "The Optimal Timing of School Tracking",

Causa, O. and C. Chapuis (2009), "Equity in Student Achievement across OECD countries: An Investigation of the Role of Policies", OECD Economics Department Working Papers, No. 708, OECD, Paris.

Cohen, G. A. (1989). On; 8the Currency of Egalitarian Justice. Ethics, 99, 06-944.

Creemers, B.P.M. and L. Kyriakides (2008), The Dynamics of Educational Effectiveness: $\quad A$ Contribution to Policy, Practice, and Theory in Contemporary Schools, Routledge, London.

DfE (2010). Sure Start Children's Centres: Statutory Guidance, London:DfE.

DfE (2011) The early years: Foundation for life, Health, and Learning. An Independent on the Early Years Foundation Stage to her Majesty's Government. Dame Clare Tickell. London: DfE.

Dontley, M.E., \& Tillman, L.C. (2006). Social justice and moral transformative leadership for social justice: Making revolutions in education. Boston. Pearson Education.

Edwards, E. and Redfem, A. (1998). At Home in School. London: Routledge.

Elias, M. J., Zins, J. E., Weissberg, R. P., Frey, K. S., Greenberg, M.T., Haynes, N. M. . . .

Shriver, T. P. (1997). Promoting social and emotional learning: Guidelines for educators. Alexanderia, VA: Association for Supervision and Curriculum Development.

Faubert, B. (2012), In-school policies and practices for overcoming school failure: $A$ Literature Review for the OECD. OECD Education Working Papers, OECD, Pari

Field S. Kuczera M. \& Pont B. (2007). Education and Training Policy. No More Failures TEN STEPS TO EQUITY IN EDUCATION Education and Training Policy Corrigenda to $O E C D$ publications may be found online at www.oecd.org/publishing/corrigenda (C) OECD 2007

Garcia Palomer, C. and R. Paredes (2010), "Reducing the Educational Gap: Good Results in Vulnerable Groups", Journal of Development Studies, Vol. 46, No. 3. 
The government of Pakistan (2009) National Education Policy. Ministry of Education Government of Pakistan Revised August 01, 2009. P. 66.

Gowda, N. S. (2015). Learning and Learner. Insights into the Processes of Learning and Teaching. Second Edition Eastern Economy Edition. PHI Learning Private Limited Delhi- 1100922015

Haut Conseil de l'Évaluation de l'École (2004), Avis 14.

Institute for the Study of Labor (IZA) Discussion Paper, No. 995.

Jennings, P.A., (2015) Mindfulness for Teachers Simple Skills for Peace and Productivity in the classroom Forwarded by Siegel, D. J. W.W. Norton \& Company New York ${ }^{\star} L o n d o n$.

Klieme, E., Ch. Pauli and K. Reusser (2009). The Pythagoras Study - Investigating the effects of teaching and learning in Swiss and German mathematics classrooms. In T. Janik and T. Seidel (Eds.), The Power of Video Studies in Investigating Teaching and Learning in the Classroom. (pp. 137-160). Münster: Waxmann

Learning First Alliance. (2001). Every child learning: Safe and supportive schools. Washington, D.C.: Author.

Levin, H. (2009) "The Economic Payoff to Investing in Educational Justice," Educational Researcher, 38(1), pp. 5-20.

Luxembourg, ministère de l'Éducation nationale et de la Formation professionnelle, $\quad 2005$, Analyse des "Klassenwiderholens" im primaren and postprimaren Bereich, www.gouvernement.lu/salle_presse/actualite/2005/09/28delvaux/etude_redoubl ment.pdf.

Mortimore, P., S. Field and B. Pont (2005), Equity in Education Thematic Review: Norway Country Note, OECD, Paris, www.oecd.org/dataoecd/10/6/35892523.pdf.

Nutbrown, C. and Hannon, P. (1997) Preparing for Early Literacy with Parents: A Professional Development Manual. Nottingham: NES Arnold.

OECD (2010b), PISA 2009 Results: What Makes a School Successful?: Resources, Policies, and Practices (Volume IV), PISA, OECD, Paris

OECD (2012), Equity and Quality in Education: Supporting Disadvantaged Students and Schools, OECD Publishing. http://dx.doi.org/10.1787/9789264130852-en

OECD, (2007). Education and Training Policy. No More Failures TEN STEPS TO EQUITY IN EDUCATION Education and Training Policy Corrigenda to OECD publications may be found online at www.oecd.org/publishing/corrigenda (C) OECD 2007

Osher, D., Dwyer, K., \& Jackson, S. (2002). Safe, supportive and successful schools: Step by step. Rockville, MD: U.S. Department of Health and Human Services, Substance Abuse and Mental Health Services Administration, Center for Mental Health Services.

Pianta, R. C. (2006). Classroom management and relationships between children and teachers: Implications for research and practice. In C. M. Evertson \& C. S. Weinstein (Eds.), Handbook of Classroom management: Research practice and contemporary issues (pp. 685-709). Mahwah, NJ: Erlbaum.

PISA (2015) Equity Draft-questionnaire-Framework.docx

Riley, R. and A. Coleman (2011), "Turning the Page on the Equity Debate in Education: How to

Give All Children a Real Opportunity", American Educator.

Rodger, R. (2012) Planning an Appropriate Curriculum in the Early Years. A guide for early years' practitioners and leaders, students and parents. (3Ed.). Routledge: London.

Scheerens, J. and R.J. Bosker (1997). The Foundations of Educational Effectiveness, Pergamon Press, Oxford.

Stiglitz, J.E., and Greenwald, (B.C. 2015, p.251). Creating a learning society. A New Approach to Growth, Development, and Social Progress. Readers' Edition. Kenneth

J. Arrow Lecture Series. Columbia University Press New York.

Stromquist, N. P. (2010) Gender Equity Education Globally. Handbook for Achieving Gender Equity through Education (2Ed.). Routledge: London.

Taylor, J.A., M.A.M. Stuhlsatz and R.W. Bybee (2009), Windows into High-Achieving Science Classrooms, in R.W. Bybee and B. McCrae (eds.), PISA Science 2006, Implications for Science Teachers and Teaching, NSTA Press, Arlington, pp. 12313 
Woessmann, L. and G. Schütz (2006), "Efficiency and Equity in European Education and Training Systems", Analytical Report for the European Commission prepared by the European Expert Network on Economics of Education (EENEE) toaccompany the Communication and Staff Working Paper by the European Commission under the same title.

World Education Forum 201519 - 22 May 2015, Incheon, Republic of Korea http://en.unesco;2.org/world-education-forum-2015/5-key-themes/equity-education 